\title{
INFLUENCE OF FIRE RETARDANT ADDITIVES ON FIRE PROPERTIES OF MATERIALS BASED ON POLYESTER RESIN POLIMAL 1033 APy
}

\author{
Jerzy GAŁAJ ${ }^{\mathrm{a}}$, Marzena PÓŁKA ${ }^{\mathrm{a}}$, Ritoldas ŠUKYS \\ ${ }^{a}$ Department of Fire Safety Engineering, The Main School of Fire Service, Slowackiego str, 52/54, \\ 01-629, Warsaw, Poland \\ ${ }^{b}$ Department of Labour Safety and Fire Protection, Vilnius Gediminas Technical University, \\ Saulètekio al. 11, 10223, Vilnius, Lithuania
}

Received 30 Jun. 2012; accepted 26 Feb. 2013

\begin{abstract}
To investigate the influence of special additives - fire retardants - on the selected fire properties of materials based on polyester resin Polimal 1033 APy produced in the chemical plant 'Organika-Sarzyna' in Poland, a full scale of fire methods has been used. Three samples have been studied during combustion in a closed compartment: an unmodified sample, a sample containing 14\% of $\mathrm{MoO}_{3}$ (molybdenum trioxide) and a sample containing $14 \%$ of antimony trioxide $\left(\mathrm{Sb}_{2} \mathrm{O}_{3}\right)$. Several important parameters related to the combustion of tested polyester materials have been obtained as a result of the undertaken studies such as temperature and carbon monoxide (CO) concentration. This paper discusses the outcome of the conducted full-scale studies. Special emphasis is placed on analysis showing variation in time of these parameters during the combustion of three different polyester materials with and without fire retardant additives. One of the most important parameters taking into account evacuation conditions is time, for reaching the critical value of both temperature and $\mathrm{CO}$ concentration that has also been considered in the study. The performed research has demonstrated that the application of the selected additives in the polyester material, in our case Polimal 1033 APy, has enhanced fire resistance of the material mainly by a significant delay of a growth in temperature and $\mathrm{CO}$ concentration and almost twice-reduced $\mathrm{CO}$ generation, particularly in the case of adding $\mathrm{Sb}_{2} \mathrm{O}_{3}$.
\end{abstract}

Keywords: polyester materials; fire retardants; Polimal 1033 APy; full-scale fire tests; thermal properties.

Reference to this paper should be made as follows: Galaj, J.; Pólka, M.; Šukys, R. 2013. Influence of fire retardant additives on fire properties of materials based on polyester resin Polimal 1033 APy, Journal of Civil Engineering and Management 19(3): 456-464.

\section{Introduction}

Polyester materials are of high significance among many types of materials applied nowadays in building engineering (building elements, division walls, glass roofs, structural elements, floor screeds). They are also used in the textile industry, automotive industry, electronics, etc.

Traditional methods for reducing flammability in plastics are based on its modification by adding fire retardants, for example curing agents or fillers. They reduce the thermal degradation process of the material subjected to radiation, which directly results in a reduction of the material combustion rate. A consequence of such a process, among the others, is a slower increase in fire temperature that brings on people evacuation conditions from the building that become more favourable.
Basically, two mechanisms of fire retardant action, including physical and chemical (Jankowska et al. 2007; Wilkie, Morgan 2009), can be distinguished. The physical mechanism of the fire retardant agent mainly consists of diluting the gas phase and forming barrier layers that block the mass flow of thermal degradation products and energy flow between gas and solid phases during material combustion. The chemical action embraces a fire retardant that enters free radical reactions of the combustion process in the gas phase and/or in reactions in the solid phase.

A disadvantage of some fire retardants is often an increase in the toxicity degree of thermal degradation products and the combustion of modified polymers in the fire environment. The products formed during combustion pose, among the others, danger to

Corresponding author. Jerzy Gałaj

E-mail: jgalaj@sgsp.edu.pl 
people during evacuation (Konecki, Półka 2006, 2009; Gałaj et al. 2012). Thus, due to the toxicity of the products of thermal degradation and combustion, in recent years, the agents consisting of halogen atoms have been substituted by halogen-free inhibitors of polymer material combustion reactions. The main directions of research to the considered field of study include the determination of susceptibility to the initiation of combustion reactions, especially under thermal and flow conditions simulating the first phase of fire, a quantitative and qualitative composition of thermal degradation products reflecting smoke-generating capacity and the toxicity of fire environment (Wilkie, Morgan 2009), the formation rate of critical heat fluxes during the combustion of epoxy materials enabling the transition from the first fire phase to the second active phase (Wilkie, Morgan 2009) as well as the influence of physical and chemical parameters of modifiers on the flammability of polyesters (Półka 2001).

A number of papers analysed and described different mechanisms of fire retardancy of polymer materials, including small-scale fire tests using standard methods like cone calorimeter, thermogravimetric analysis, limited oxygen index, differential scanning calorimeter and vertical burning test (UL94) (Półka 2001; Konecki, Półka 2006, 2009; Kandare et al. 2008; Laoutid et al. 2009; Pereira et al. 2009; Fukushima et al. 2010; Kiliaris, Papaspyrides 2010; Seetapan et al. 2011; Tibiletti et al. 2011; Wei et al. 2011; Carosio et al. 2012; Li et al. 2012; Pan et al. 2012; Tang et al. 2012). Several studies focus on the fire modelling of polymer composites (Mouritz et al. 2009; Konecki, Półka 2009). Although a full scale of fire tests has been used for investigating, the influence of fire retardants on the combustion process of pine timber end epoxy resin has been conducted (Gałaj 2008; Gałaj et al. 2011a, b, 2012); comparable experiments on polyester materials are still required. This article is aimed at filling the gap in full-scale fire tests on the above-mentioned materials, including fire retardants.

In order to determine the influence of fire retardants on the flammability properties of polyester materials, this paper presents a comparative analysis of the impact of two additives - antimony trioxide $\left(\mathrm{Sb}_{2} \mathrm{O}_{3}\right)$ and molybdenum trioxide $\left(\mathrm{MoO}_{3}\right)$ - retarding the combustion process on pure polyester resin (PES) Polimal 1033 APy. In the experimental part, full-scale fire tests, discussing three samples of polyester materials were carried out. This study defined temperature and carbon monoxide (CO) in the selected locations of the compartment during sample combustion. Smallscale tests on similar materials applying the cone calorimeter method etc. will be the objective of another paper.

\section{Subject of the study}

For experimental studies, a trade name of PES Polimal 1033 APy produced in the chemical plant OrganikaSarzyna in Nowa Sarzyna, Poland was used. The material is very often applied for building engineering and is made of low viscosity, medium elastic, and preaccelerated structural resin. An abbreviation at the end of the name stands for ecological, low styrene emission (letter A) and accelerated resin, which does not require the use of cobalt accelerator (symbol Py). The basic parameters of resin are given in Table 1 (Półka 2001).

For the modification of Polimal 1033 Apy resin, two non-organic oxides were used: $\mathrm{Sb}_{2} \mathrm{O}_{3}$ and $\mathrm{MoO}_{3}$, i.e. modifications aimed at enhancing fire resistance properties of resin. A quantity of the added fire retardants was selected experimentally. Concentration range of modifiers depended on visible changes in a particular fire property of the lowest modifier concentration and a lack of a registered change in the same parameter of fire above the highest applied concentration of the modifier. For selecting nonorganic filler, changes in resin viscosity and gelation time were taken into account. The method of modification for both additives was the same. Both modifiers were added to PES obtained as a result of polycondensation at a temperature of $t=25{ }^{\circ} \mathrm{C}$ and pressure $\mathrm{p}=0$ atm (Półka 2001).

Physical and chemical properties of the applied $\mathrm{Sb}_{2} \mathrm{O}_{3}$ are as follows:

(1) the degree of fragmentation $-23 \mathrm{~m}$;

(2) the degree of purity $>99 \%$ (specified by a manufacturer);

(3) slightly soluble in water;

(4) melting temperature $=656{ }^{\circ} \mathrm{C}$.

Physical and chemical properties of $\mathrm{MoO}_{3}$ are as follows:

(1) the degree of fragmentation - from 2 to $10 \mathrm{~m}$;

(2) the degree of purity $>99 \%$ (specified by a manufacturer);

(3) slightly soluble in water;

(4) melting temperature $=795{ }^{\circ} \mathrm{C}$.

Table 1. Parameters of Polimal 1033 APy PES

\begin{tabular}{ll}
\hline Non-volatile part $(\% \mathrm{wt})$. & $64 \pm 3$ \\
Acid value $(\mathrm{mg} \mathrm{KOH} / \mathrm{g})$ & 35 \\
Viscosity at $25{ }^{\circ} \mathrm{C}(\mathrm{mPa} \cdot \mathrm{s})$ & $300-400$ \\
Density at $25{ }^{\circ} \mathrm{C}\left(\mathrm{g} / \mathrm{cm}^{3}\right)$ & 1.12 \\
Gelation time at. $25{ }^{\circ} \mathrm{C}(\mathrm{min})$ & $12 \pm 5$ \\
Temperature of deflation under load (HDT) $\left({ }^{\circ} \mathrm{C}\right)$ & 60 \\
Breaking stress $(\mathrm{MPa})$, tensile strength $(\mathrm{MPa})$ & 55 \\
Bending strength $(\mathrm{MPa})$ & 85 \\
Tensile modulus $(\mathrm{MPa})$ & 3000 \\
unit elongation at tension $(\%)$ & 2 \\
Impact resistance $\left(\mathrm{kJ} / \mathrm{m}^{2}\right)$ & 8 \\
Barcol hardness $\left({ }^{0} \mathrm{~B}\right)$ & 35 \\
\hline
\end{tabular}


(a)

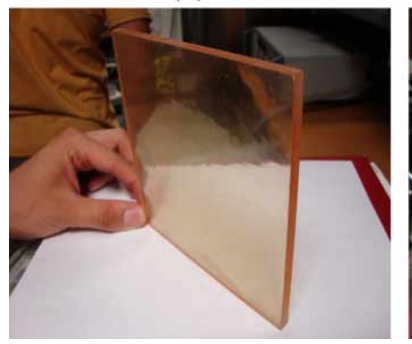

(b)

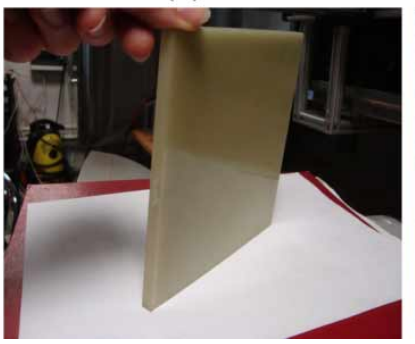

(c)

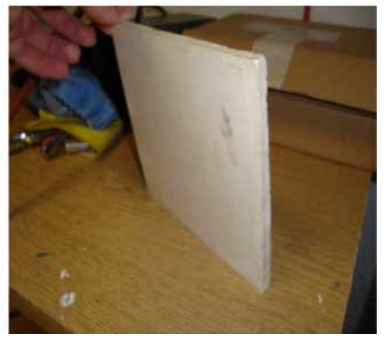

Fig. 1. Polyester samples applied for studies: (a) unmodified sample; (b) sample modified with $\mathrm{MoO}_{3}$; and (c) sample modified with $\mathrm{Sb}_{2} \mathrm{O}_{3}$

For full-scale studies, pure PES polyester (transparent sample) samples and modified samples containing $14 \%$ of $\mathrm{MoO}_{3}$ (green colour sample) or $\mathrm{Sb}_{2} \mathrm{O}_{3}$ (white colour sample) were used and selected due to the best fire resistance properties from three samples of a different content of additives (7\%, 14\% and 21\%) tested employing the cone calorimeter method (Półka 2001). Figure 1 shows the applied samples (Zowada 2010).

\section{Test stand and measuring methods}

Full-scale studies on temperature distribution and $\mathrm{CO}$ concentration during the combustion of the studied materials were conducted in the test chamber measured as $5 \times 5 \times 2.8 \mathrm{~m}$. The chamber was restricted from two sides by reinforced glass-aluminium walls. Two remaining walls were made of bricks with outer lining made of ceramic tiles. Internal and external views of the test chamber are shown in Figures 2 and 3 (Mizerski 2011).

A research compartment was equipped with measuring devices enabling recording temperature at hundred different locations and concentrations of gases $(\mathrm{CO})$ at six points. The presented work mainly focuses on the studies related to the distribution of temperature and CO. For temperature measurement, hundreds of thermocouples of type TP 201K-300-15 mounted on steel ropes were employed. On each rope,

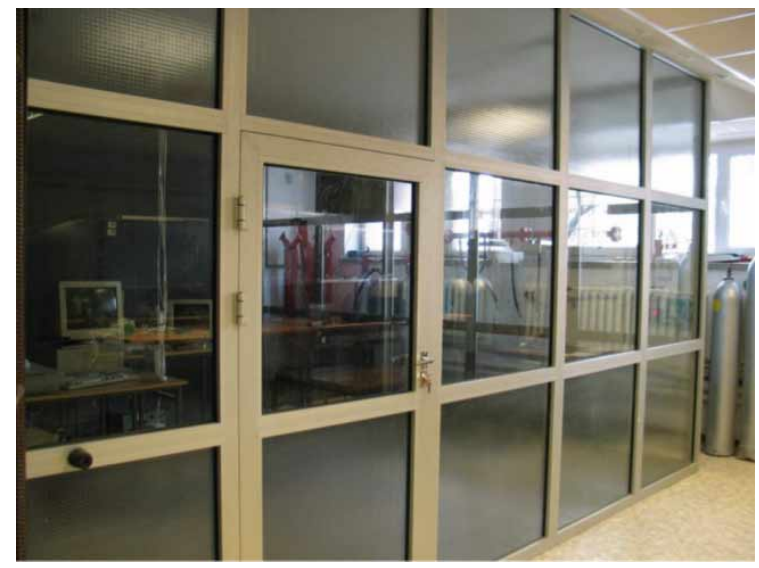

Fig. 2. An external view of the test chamber five sensors at different heights were placed: $0.8 \mathrm{~m}$ (level 1); $1.5 \mathrm{~m}$ (level 2); $2.0 \mathrm{~m}$ (level 3); $2.5 \mathrm{~m}$ (level 4); and $2.7 \mathrm{~m}$ (level 5). The arrangement of thermocouples in horizontal and vertical planes as well as their numbering is shown in Figure 4 (Gałaj 2008).

For measuring gas concentrations, six sensors located on aluminium posts (A, B and C) at three different heights of $1.6 \mathrm{~m}$ (head level of human) and $2.7 \mathrm{~m}$ (ceiling zone) above the floor level were applied. Each sensor was equipped with MMG-72 measurement head manufactured by ALTER S.A. The heads were dedicated for communicating with stationary control unit MSMR-4, including external safe circuits marked II (2)G [Ex ia] IIC and adjusted to specifying the measurement head. The heads are designed to be used in hazardous areas, classified as zone 1 and zone 2 gas, steam or mist explosion areas, explosion groups IIA, IIB and IIC and temperature classes T1, T2, T3 and T4. The arrangement of gas concentration sensors is presented in Figure 5 (Gałaj 2008).

For computer registering, the values of measuring signals corresponding to temperature (signals from thermocouples) and $\mathrm{CO}$ concentration (signal from sensors), measuring modules, including ADAM series analogue-digital converters produced by Advantech were used. For the conversion of output signals from thermocouples, ADAM 4019 modules were applied while the rest employed ADAM 4017. All measuring

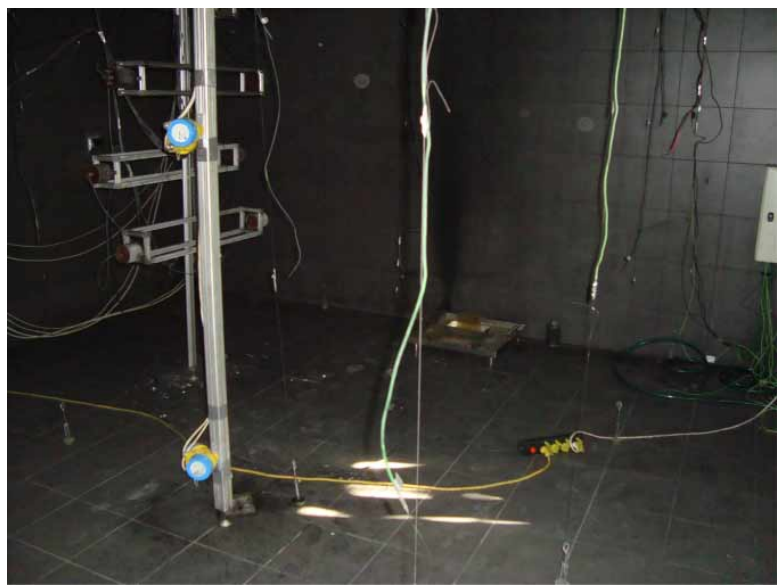

Fig. 3. An internal view of the test chamber 


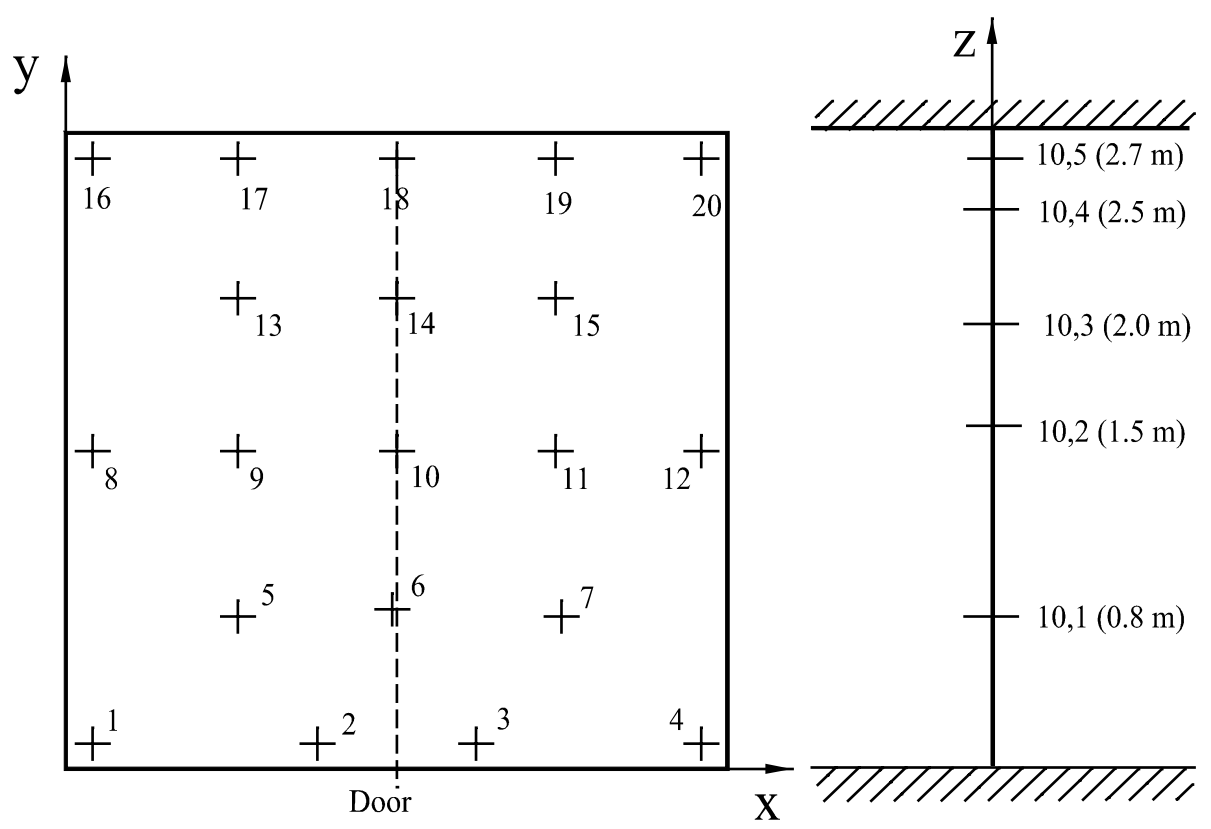

Fig. 4. The arrangement of thermocouples in horizontal and vertical planes (example for tree no. 10)

signals from converters meeting the RS 485 standard were transferred to ADAM 4520 converter, the output signal of which regarding RS 232 standard is directed to the serial port of the computer. A simplified scheme for the measuring system is given in Gałaj (2008). For the readout, conversion and data registering from measuring devices AdamView software were applied. It is a straightforward and relatively cheap software enabling building not very complex applications dedicated to measurements and simple automation. It also enables data exchange between the computer and I/O modules, simple visualisation (including charts but without a possibility of printing out) as well as saving data on the disk (e.g. in a tabular form to the text file). Additionally, the functionality of software can be extended in-house by accepting a possibility of writing our own VBA (Visual Basic for Applications) scripts or by sharing data with other applications, e.g. Microsoft Access and Microsoft Excel.

\section{Description and results of the study}

For conducting studies, a polyester material in a cuboidal form having the dimensions of $0.15 \times 0.15 \times$ $0.005 \mathrm{~m}$ was used. In each series of the made measurements, two samples of the same material (pure resin PES, PES with $\mathrm{Sb}_{2} \mathrm{O}_{3}$, PES with $\mathrm{MoO}_{3}$ ) were placed on a metal tray in a way they contacted along upper edges. Next, $0.250 \mathrm{dm}^{3}$ of denatured alcohol was injected into space between the samples, and was afterwards ignited when placed in the test chamber. The tray with samples was every time positioned at the same location next to the wall of the chamber. Figure 6 shows the example of polyester samples prepared for the test and during the test (Zowada 2010).
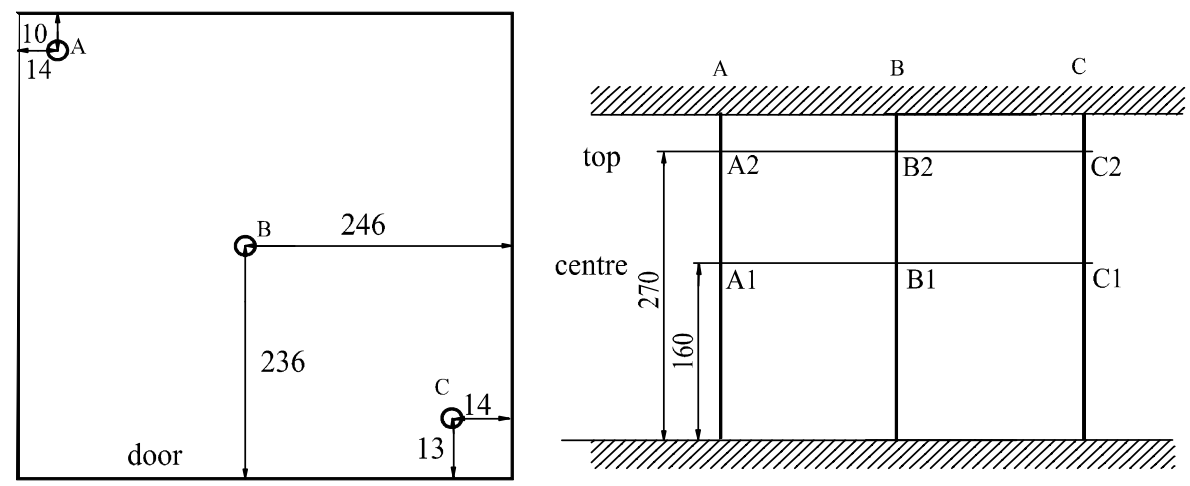

Description:

A,B,C - aluminium columns with carbon monoxide sensors

Fig. 5. The arrangement of gas concentration sensors (A1, A2, B1, B2, C1 i C2) in horizontal and vertical planes 

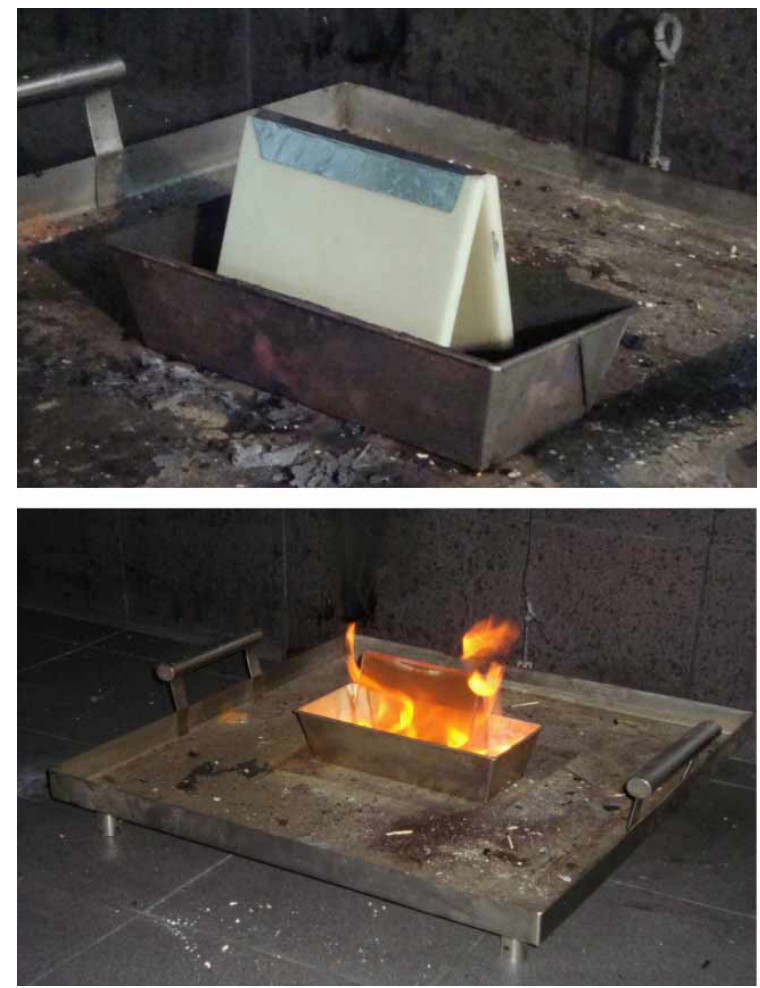

Fig. 6. A modified polyester sample prepared for the test (top) and an unmodified sample during the test (bottom)

Residues of the studied materials after the test are presented in Figure 7 (Zowada 2010).

After the time specified by the researchers (at the beginning of the extinction phase), mechanical airconditioning was turned on with capacity corresponding to 10 air exchanges per hour. This time was different for each sample:

a) $1075 \mathrm{~s}$ for unmodified resin (sample 1);

b) $820 \mathrm{~s}$ for resin with molybdenum $\left(\mathrm{MoO}_{3}\right)$ addition (sample 3);

c) $1900 \mathrm{~s}$ for resin with antimony $\left(\mathrm{Sb}_{2} \mathrm{O}_{3}\right)$ addition (sample 2).

Data were registered until $\mathrm{CO}$ concentration dropped to zero. Then, data registering was stopped. At the end, the samples were inspected visually, and after reaching the initial conditions (temperature and concentration), the following tests were performed. All

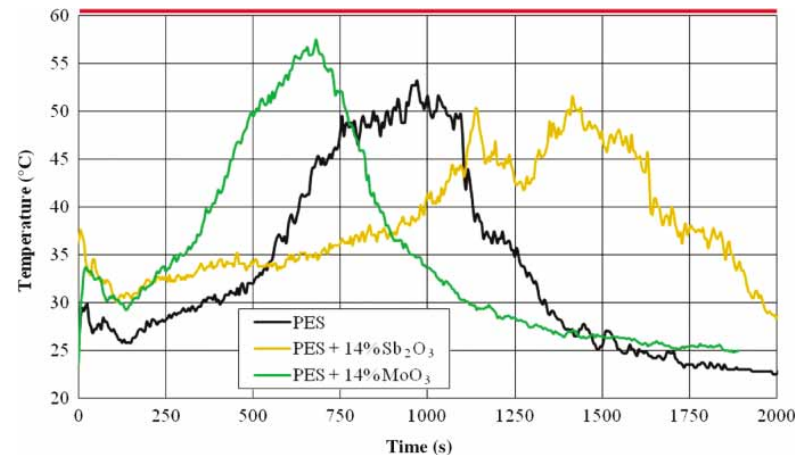

Fig. 8. Temperature curves registered by the thermocouple placed on tree 18 at a height of $2.7 \mathrm{~m}$ for three studied samples

three samples 1,2 and 3 were tested two times in the same manner and conditions. The results were statistically processed and the most expected values of parameters were taken to further analysis.

Based on the temperatures registered at hundred points of the compartment, tree 18 having the highest registered values was chosen. The curves of temperatures obtained at the heights of $2.7 \mathrm{~m}$ (ceiling zone) and $1.5 \mathrm{~m}$ (zone significant from the evacuation conditions point of view) during combustion of three tested polyester materials are shown in Figures 8 and 9 .

$\mathrm{CO}$ concentrations time series registered by $\mathrm{A} 1$ (post $\mathrm{A}$ at $1.6 \mathrm{~m}$ ) and $\mathrm{A} 2$ (post $\mathrm{A}$ at $2.7 \mathrm{~m}$ ), B1 (post B at $1.6 \mathrm{~m}$ ) and $\mathrm{B} 2$ (post $\mathrm{B}$ at $2.7 \mathrm{~m}$ ) as well as $\mathrm{C} 1$ (post $\mathrm{C}$ at $1.6 \mathrm{~m}$ ) sensors for three studied samples 1,2 and 3 are shown in Figures 10-14.

Table 2 presents the values of the selected fire parameters such as the maximum temperature value and time for reaching it, the rate of a rise in temperature and time following which it reaches a specified critical value of $60^{\circ} \mathrm{C}$ (Zowada 2010). It can be useful for a comparison of temperature distribution for tested samples. Similarly, Table 3 gives the values of the selected parameters related to the distribution of $\mathrm{CO}$ concentration: maximum $\mathrm{CO}$ concentration and time for reaching it, the average rate of a rise in concentration, time for reaching a critical value assumed at the level of $100 \mathrm{ppm}$ (according with the order of the Ministry of Labour and Social Politics (a)

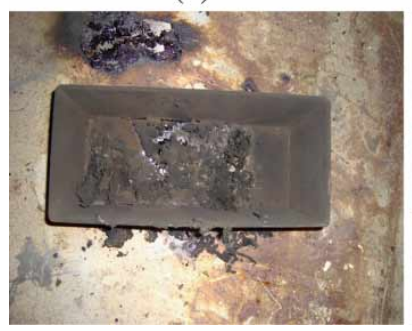

(b)

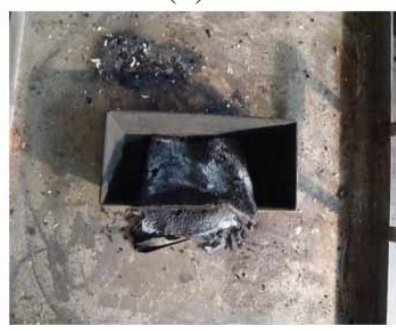

(c)

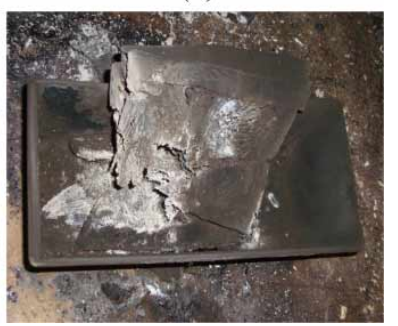

Fig. 7. Residues of the studied materials after combustion: (a) unmodified PES (sample 1); (b) modified with $\mathrm{MoO}_{3}$ (sample 2); (c) modified with $\mathrm{Sb}_{2} \mathrm{O}_{3}$ (sample 3) 


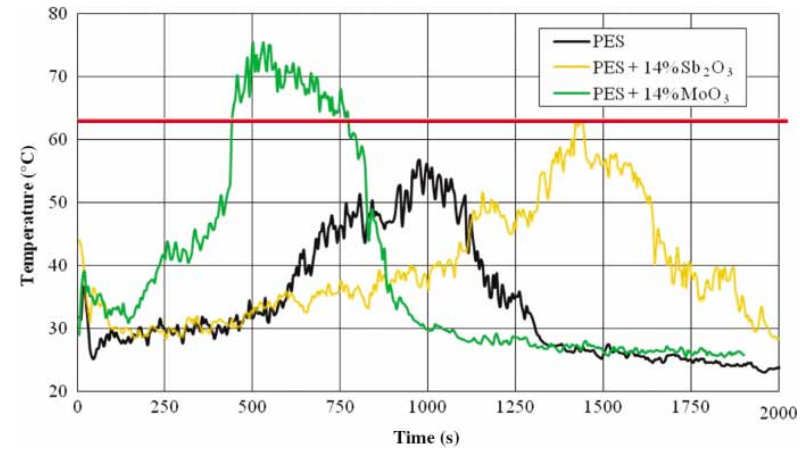

Fig. 9. Temperature curves registered by the thermocouple placed on tree 18 at a height of $1.5 \mathrm{~m}$ for three studied samples

issued on 29 November 2002). Data included in the tables were used for comparing the distribution of concentration during the combustion of three studied samples of polyester materials.

\section{Analysis of results}

On the basis of the registered temperature time series during the combustion of three different polyester samples unmodified and modified with fire retardants such as antimony and $\mathrm{MoO}_{3}$ and with reference to the visual inspection of the residues of samples as well as the analysis of the whole process, the below presented properties of the tested processes have been observed.

The highest fire development rate, with the average rate of temperature growth making $0.11{ }^{\circ} \mathrm{C} / \mathrm{s}$, has been observed for the sample with an addition of $\mathrm{MoO}_{3}$ (sample 3). Fire duration time, in this case, was the shortest, and the maximum temperature $\left(76^{\circ} \mathrm{C}\right)$ was reached following approximately $530 \mathrm{~s}$ from the start of ignition. The lowest rate of fire development has been demonstrated for a polyester material with an addition of $\mathrm{Sb}_{2} \mathrm{O}_{3}$ (sample 2). An average rate of a rise in temperature was $0.03{ }^{\circ} \mathrm{C} / \mathrm{s}$. In this case, a lower value of the maximum temperature of $63{ }^{\circ} \mathrm{C}$ was obtained following $1420 \mathrm{~s}$, whereas the combustion process was the longest. Within the combustion

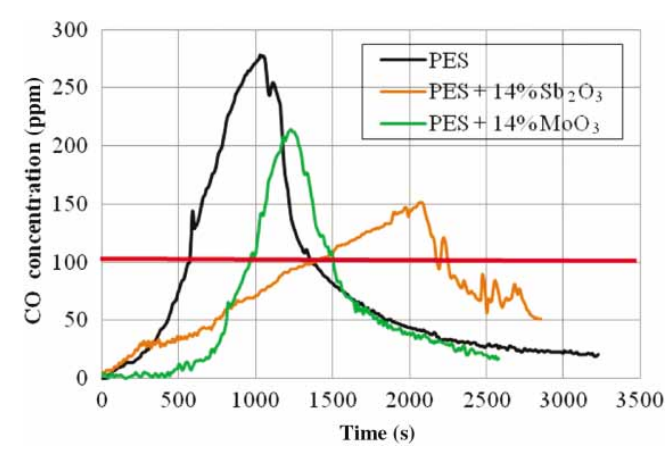

Fig. 10. CO concentration time series registered by $\mathrm{A} 1$ sensor located at the corner of the compartment (post A) at $1.6 \mathrm{~m}$ for three studied samples

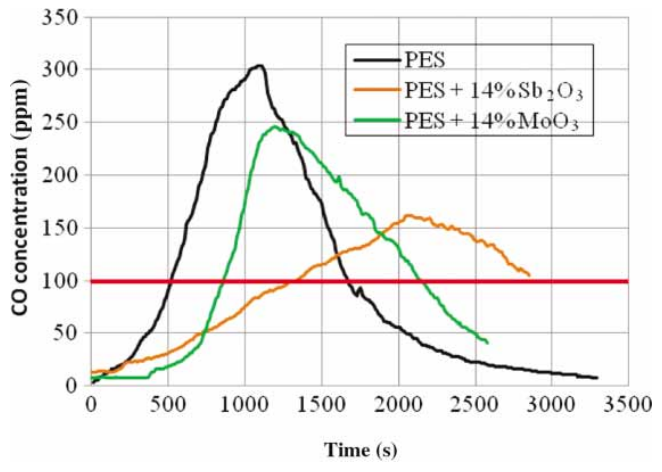

Fig. 11. CO concentration time series registered by A2 sensor located at the corner of the compartment (post A) at $2.7 \mathrm{~m}$ for three studied samples

process of the unmodified polyester material (sample 1), the obtained maximum value was $59{ }^{\circ} \mathrm{C}$ after a relatively long time of about $1120 \mathrm{~s}$. In all studied cases (except the PES sample modified with $\mathrm{MoO}_{3}$ in the ceiling zone), rapid variations in temperature up to $5{ }^{\circ} \mathrm{C}$ were observed and appeared to be close to the maximum values.

A critical temperature of $60{ }^{\circ} \mathrm{C}$ was the fastest to exceed (following about $350 \mathrm{~s}$ from ignition) during the combustion of PES with an addition of $\mathrm{MoO}_{3}$ (sample 3). The longest time for reaching a critical value was obtained during the combustion of polyester with $\mathrm{Sb}_{2} \mathrm{O}_{3}$ (sample 2) and made 1070 s. An intermediate time of about $650 \mathrm{~s}$ was registered for a pure sample without additives (sample 1).

Based on the obtained temperature time series (see Figs 8 and 9), two phases of the developed fire can be distinguished: the first one is characterised by lower maximum temperature and the second when temperature reaches the global maximum. This phenomenon can be clearly visible in case of PES with an addition of $\mathrm{Sb}_{2} \mathrm{O}_{3}$ (sample 2). Such temperature curve is typical of materials with a complex structure. In the ceiling zone, differences between amplitudes practically disappear. The largest difference of about $32{ }^{\circ} \mathrm{C}$ was observed at $1.5 \mathrm{~m}$ during the combustion of PES with

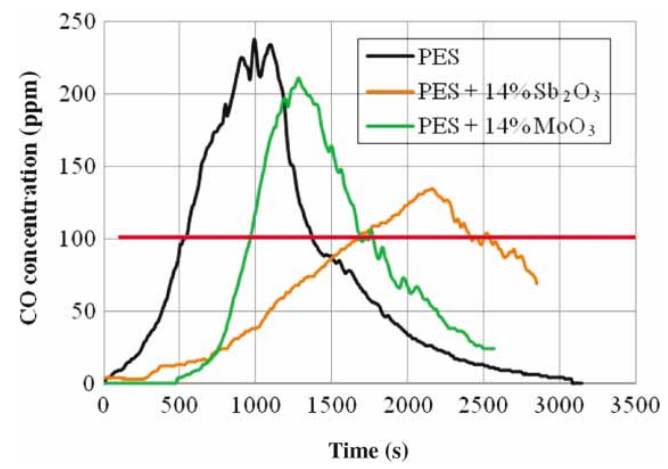

Fig. 12. CO concentration time series registered by $\mathrm{B} 1$ sensor located at the centre of the compartment (post B) at $1.6 \mathrm{~m}$ for three studied samples 


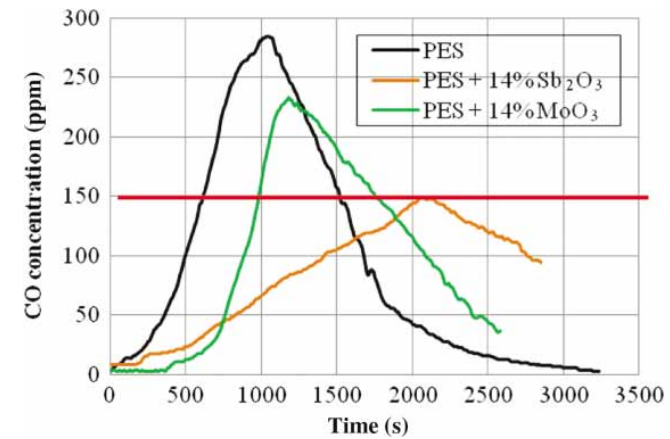

Fig. 13. CO concentration time series registered by $\mathrm{B} 2$ sensor located at the centre of the compartment (post B) at $2.7 \mathrm{~m}$ for three studied samples

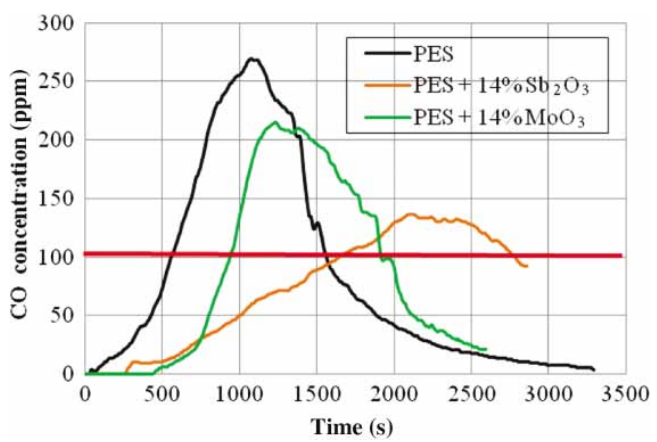

Fig. 14. $\mathrm{CO}$ concentration time series registered by $\mathrm{C} 1$ sensor located at the corner of the compartment (post C) at $1.6 \mathrm{~m}$ for three studied samples

$\mathrm{MoO}_{3}$ (sample 3). The slightest difference of about $5{ }^{\circ} \mathrm{C}$ was demonstrated by temperature time series during the combustion of PES without additives (sample 1).

Temperature higher or equal to $40{ }^{\circ} \mathrm{C}$, likely to cause burn in prolonged contact with skin, remained longest (about $630 \mathrm{~s}$ ) during the combustion of the material with an addition of $\mathrm{Sb}_{2} \mathrm{O}_{3}$ (sample 2). In the remaining two cases, this time was similar and made about $500 \mathrm{~s}$.

Residues remained after combustion and differed significantly from each other. Polyester material without additives was combusted almost totally and only some small amount of incinerated solid particles remained (see Fig. 7a). The largest quantity of material elements remained after the combustion of the material with an addition of $\mathrm{Sb}_{2} \mathrm{O}_{3}$ (see Fig. 7c), whereas a slightly lower quantity - after the combustion of a sample containing $\mathrm{MoO}_{3}$ (see Fig. 7b).

The material with an addition of $\mathrm{Sb}_{2} \mathrm{O}_{3}$ turned out to be difficult to ignite, and following several attempts of ignition, the combustion process was initiated.

Based on the registered $\mathrm{CO}$ concentration time series during the combustion of three different samples of unmodified and modified polyester materials with antimony and $\mathrm{MoO}_{3}$ fire retardants, the following properties of the tested process have been observed.

During the combustion of unmodified resin (sample 1), practically from the very beginning of combustion, a growth in linear $\mathrm{CO}$ concentration up to about $400 \mathrm{~s}$ can be observed following a rapid growth with an average rate of $0.27 \mathrm{ppm} / \mathrm{s}$. After approximately $1030 \mathrm{~s}$, it has reached the maximum value of $278 \mathrm{ppm}$. Time for reaching a critical value of $100 \mathrm{ppm}$, in this case, was $570 \mathrm{~s}$.

An addition of fire retardants caused a delay in releasing $\mathrm{CO}$. For instance, in case of $\mathrm{MoO}_{3}$ (sample 3 ), the presence of $\mathrm{CO}$ in the centre of the compartment at $1.6 \mathrm{~m}$ was observed after $500 \mathrm{~s}$ from ignition. In the ceiling zone, a slightly faster appearance of this

Table 2. Basic parameters characterising temperature distribution during the combustion of modified and unmodified polyester materials

\begin{tabular}{lcccr}
\hline $\begin{array}{l}\text { Polyester } \\
\text { materials }\end{array}$ & $\begin{array}{c}\text { Maximum temperature/ } \\
\text { thermocouple number }\left({ }^{\circ} \mathrm{C}\right)\end{array}$ & $\begin{array}{c}\text { Time to reach a maximum } \\
\text { temperature }(\mathrm{s})\end{array}$ & $\begin{array}{c}\text { Average rate of } \\
\text { temperature rise }\left({ }^{\circ} \mathrm{C} / \mathrm{s}\right)\end{array}$ & $\begin{array}{r}\text { Time to reach a } \\
\text { critical value }(\mathrm{s})\end{array}$ \\
\hline PES & $59 / 18.1$ & 1120 & 0.09 & 650 \\
$\mathrm{PES}+14 \% \mathrm{Sb}_{2} \mathrm{O}_{3}$ & $63 / 18.2$ & 1420 & 0.03 & 1070 \\
$\mathrm{PES}+14 \% \mathrm{MoO}_{3}$ & $76 / 18.2$ & 530 & 0.11 & 350 \\
\hline
\end{tabular}

Table 3. Basic parameters characterising CO distribution during the combustion of modified and unmodified polyester materials

\begin{tabular}{lcccc}
\hline & $\begin{array}{c}\text { Maximum } \mathrm{CO} \\
\text { Polyester materials }\end{array}$ & $\begin{array}{c}\text { Time to reach a } \\
\text { maximum concentration } \\
\text { concentration }(\mathrm{ppm})\end{array}$ & $\begin{array}{c}\text { Time to reach a critical } \\
\text { concentration of 100 ppm } \\
(\mathrm{s})\end{array}$ & $\begin{array}{c}\text { Average rate of } \\
\text { concentration rise } \\
(\mathrm{ppm} / \mathrm{s})\end{array}$ \\
\hline $\mathrm{PES}$ & 278 & 1030 & 570 & 0.27 \\
$\mathrm{PES}+14 \% \mathrm{Sb}_{2} \mathrm{O}_{3}$ & 151 & 2070 & 1370 & 0.07 \\
$\mathrm{PES}+14 \% \mathrm{MoO}_{3}$ & 235 & 1230 & 900 & 0.19 \\
\hline
\end{tabular}


toxic product was registered (after about $400 \mathrm{~s}$ ). When adding $\mathrm{Sb}_{2} \mathrm{O}_{3}$ (sample 2), the time of $\mathrm{CO}$ occurrence was much shorter and varied in a range between 40 and $280 \mathrm{~s}$.

The lowest average increase in $\mathrm{CO}$ concentration of $0.07 \mathrm{ppm} / \mathrm{s}$ was obtained during the combustion of PES modified with $\mathrm{Sb}_{2} \mathrm{O}_{3}$ (sample 2). In case of the combustion of PES with $\mathrm{MoO}_{3}$ (sample 3), this value was twice higher and equal to $0.19 \mathrm{ppm} / \mathrm{s}$. It is related to time for reaching a critical value of $100 \mathrm{ppm}$, which, in case of PES with $\mathrm{Sb}_{2} \mathrm{O}_{3}$ (sample 2), was clearly the longest and made $1370 \mathrm{~s}$. For PES with an addition of $\mathrm{MoO}_{3}$ (sample 3), it was significantly shorter and reached about $900 \mathrm{~s}$.

The maximum value of $\mathrm{CO}$ concentration for PES with $\mathrm{Sb}_{2} \mathrm{O}_{3}$ (sample 2) was equal to $151 \mathrm{ppm}$ and significantly lower than that for PES with molybdenum $(235 \mathrm{ppm})$ and for pure PES (278 ppm). The maximum values of $\mathrm{CO}$ concentration measured by the sensors mounted on aluminium post $\mathrm{C}$ were averagely about $50 \mathrm{ppm}$ lower than those measured by the sensors located on post A. A reason for that may be the fact that it was located closer to the fire source. Moreover, post $\mathrm{C}$ was placed near the walls made of glass, while post A was placed near the walls covered with ceramic tiles.

\section{Conclusions}

Based on the analysis of the obtained results included in Chapter 4, the following conclusions have been formulated:

(1) Taking into consideration all parameters affecting safety evacuation conditions (rate of a rise in temperature and $\mathrm{CO}$ concentration, maximum values and especially time for reaching a critical value), it can be concluded that the addition of $\mathrm{Sb}_{2} \mathrm{O}_{3}$ to pure PES resulted in the significant suppression of flammability. It manifested itself by significantly slower temperature and $\mathrm{CO}$ growth during combustion, which reflected prolonged time for reaching a critical value (about $140 \%$ for the sample with $\mathrm{Sb}_{2} \mathrm{O}_{3}$ and $58 \%$ for the sample with $\mathrm{MoO}_{3}$ ) and significantly lower maximum concentrations even below $150 \mathrm{ppm}$. The average reduction in $\mathrm{CO}$ generation by approximately $46 \%$ in case of the additive of $\mathrm{Sb}_{2} \mathrm{O}_{3}$ (sample 2) and about $15 \%$ in case of $\mathrm{MoO}_{3}$ (sample 3) can be observed;

(2) Regarding temperature, maximum values are similar; however, time for reaching them is longer if compared to the unmodified material (sample 1) of about $300 \mathrm{~s}$. Applying the additive in a form of $\mathrm{MoO}_{3}$ (sample 3) does not give such unequivocal results. Although time for reaching critical concentration is $300 \mathrm{~s}$ longer and the maximum concentration is slightly lower, still, time for reaching the maximum temperature is more than twice shorter and the maximum value is almost $20{ }^{\circ} \mathrm{C}$ higher comparing to pure polyester material (sample 1). These suspected changes in fire properties using physical additives of fire retardants are very important from the fire safety point of view, because they enable to extend time required for people evacuation during the combustion of properly modified polyester materials;

(3) With reference to the conducted studies, it can be concluded that $\mathrm{Sb}_{2} \mathrm{O}_{3}$ is a much better fireproof agent taking into account PES Polimal 1033 APy. It should be noticed that only $225 \mathrm{~cm}^{3}$ of the material was combusted. During fire where larger quantities of such materials are present, respectively higher temperatures and $\mathrm{CO}$ concentrations are likely to occur; however, their values during combustion as well as the influence of the applied fire retardants is expected to be similar.

\section{References}

Carosio, F.; Alongi, J.; Malucelli, G. 2012. Layer by Layer ammonium polyphosphate-based coatings for flame retardancy of polyester-cotton blends, Carbohydrate Polymers 88(4): 1460-1469.

http://dx.doi.org/10.1016/j.carbpol.2012.02.049

Fukushima, K.; Murariu, M.; Camino, G.; Dubois, P. 2010. Effect of expanded graphite/layered-silicate clay on thermal, mechanical and fire retardant properties of poly(lactic acid), Polymer Degradation and Stability 95(6): 1063-1076.

http://dx.doi.org/10.1016/j.polymdegradstab.2010.02.029

Gałaj, J. 2008. Analiza porównawcza zmian temperatury oraz stężeń tlenu i tlenku węgla w pomieszczeniu nie wentylowanym podczas pożaru pianki poliuretanowej i drewna sosnowego [Comparative analysis of the changes of temperature as well as oxygen and carbon monoxide concentrations in unventilated compartment during polyurethane foam and pine wood fire], Zeszyty Naukowe SGSP 36: 41-60.

Gałaj, J.; Jaskółowski, W.; Karpovic, Z.; Šukys, R. 2011 a. Investigation of the influence of impregnation on the pine timber combustion using flow through tests, Bezpieczeństwo i Technika Pożarnicza [Safety and Fire Technique] 23(3): 55-62.

Gałaj, J.; Karpovic, Z.; Jaskółowski, W. 2011b. Investigation into the influence of impregnation on pine timber combustion using a cone calorimeter and large scale tests, Engineering Structures and Technologies 3(3): 91-104. http://dx.doi.org/10.3846/skt.2011.11

Gałaj, J.; Półka, M.; Wnęk, W. 2012. Influence of additive fire retardants on some fire properties of epoxy materials, Przemyst Chemiczny 91(7): 1000-1006.

Jankowska, G.; Przygocki, W.; Włochowicz, A. 2007. Palność polimerów $i$ materiałów polimerowych [Flammability of polymers and polymeric materials]. Warsaw: WNT. $344 \mathrm{p}$.

Kandare, E.; Kandola, B. K.; Price, D.; Nazaré, S.; Horrocks, R. A. 2008. Study of thermal decomposition of flame-retarded unsaturated polyester resins by thermogravimetric analysis and Py-GC/MS, Polymer Degradation and Stability 93(11): 1996-2006. http://dx.doi.org/10.1016/j.polymdegradstab.2008.03.032 
Kiliaris, P.; Papaspyrides, C. D. 2010. Polymer/layered silicate (clay) nanocomposites: an overview of flame retardancy, Progress in Polymer Science 35(7): 902-958. http://dx.doi.org/10.1016/j.progpolymsci.2010.03.001

Konecki, M.; Półka, M. 2006. Analiza zasięgu widzialności w dymie powstałym w czasie spalania materiałów poliestrowych [Analysis of visibility range in a smoke produced during combustion of polyester materials], Polimery 51(4): 46-53.

Konecki, M.; Pólka, M. 2009. Analiza rozprzestrzeniania się ciepła i dymu w czasie spalania wybranych materiałów poliestrowych [Analysis of heat and smoke spreading during combustion of chosen polyester material], Przemyst Chemiczny 88(2): 4-14.

Laoutid, F.; Bonnaud, L.; Alexandre, M.; Lopez-Cuesta, J.-M.; Dubois, P. 2009. New prospects in flame retardant polymer materials: From fundamentals to nanocomposities, Materials Science and Engineering: R: Reports 63(3): 100-125. http://dx.doi.org/10.1016/j.mser.2008.09.002

Li, N.; Xia, Y.; Mao, Z.; Wang, L.; Guan, Y.; Zheng, A. 2012. Influence of antimony oxide on flammability of polypropylene/intumescent flame retardant system, Polymer Degradation and Stability 97(9): 1737-1744. http://dx.doi.org/10.1016/j.polymdegradstab.2012.06.011

Mizerski, R. 2011. Badanie rozkładów stężén tlenku wegla podczas spalania materiałów poliestrowych $w$ pomieszczeniu zamkniętym [Investigation of carbon monoxide concentration during combustion of polyester materials in a closed compartment]. Master thesis, SGSP.

Mouritz, A. P.; Feih, S.; Kandare, E.; Mathys, Z.; Gibson, A. G.; Des Jardin, P. E.; Case, S. W.; Lattimer, B. Y. 2009. Review of fire structural modelling of polymer composites, Composites Part A: Applied Science and Manufacturing 40(12): 1800-1814. http://dx.doi.org/10.1016/j.compositesa.2009.09.001

Pan, L. L.; Li, G. Y.; Su, Y. C.; Lian, J. S. 2012. Fire retardant mechanism analysis between ammonium polyphosphate and triphenyl phosphate in unsaturated polyester resin, Polymer Degradation and Stability 97(9): 1801-1806.

http://dx.doi.org/10.1016/j.polymdegradstab.2012.06.002

Pereira, C. M. C.; Herrero, M.; Labajos, F. M.; Marques, A. T.; Rives, V. 2009. Preparation and properties of new flame retardant unsaturated polyester nanocomposites based on layered double hydroxides, Polymer Degradation and Stability 94(6): 939-946.

http://dx.doi.org/10.1016/j.polymdegradstab.2009.03.009
Półka, M. 2001. Wpływ dodatków nieorganicznych na palność modyfikowanych materiatów poliestrowych [Influence of inorganic additives on flammability of modified polyester materials]. PhD Thesis. Technical University in Szczecin.

Rozporzadzenie Ministra Pracy i Polityki Społecznej z 29 listopada 2002 r. w sprawie najwyższych dopuszczalnych stężeń i natężeń czynników szkodliwych dla zdrowia $\mathrm{w}$ srodowisku pracy [A government order of Ministry of Labour and Social Politics on 29 November 2002 concerning highest permissible concentrations and intensity of the factors harmful for health in labour environment]. Dz.U. 2002 nr 217 poz. 1833.

Seetapan, N.; Limparyoon, N.; Kiatkamjornwong, S. 2011. Effect of fire retardant on flammability of acrylamide and 2-acrylamido-2-methylpropane sodium sulfonate copolymer composites, Polymer Degradation and Stability 96(10): 1927-1933.

http://dx.doi.org/10.1016/j.polymdegradstab.2011.06.014

Tang, Z.; Li, Y.; Zhang, Y. J.; Jiang, P. 2012. Oligomeric siloxane containing triphenylphosphonium phosphate as a novel flame retardant for polycarbonate, Polymer Degradation and Stability 97(4): 638-644. http://dx.doi.org/10.1016/j.polymdegradstab.2012.01.002

Tibiletti, L.; Longuet, C.; Ferry, L.; Coutelen, P.; Mas, A.; Robin, J.-J.; Lopez-Cuesta, J.-M. 2011. Thermal degradation and fire behaviour of unsaturated polyesters filled with metallic oxides, Polymer Degradation and Stability 96(1): 67-75. http://dx.doi.org/10.1016/j.polymdegradstab.2010.10.015

Wei, L.-L.; Wang, D.-Y.; Chen, H.-B; Chen, L.; Wang, X.-L.; Wang, Y.-Z. 2011. Effect of phosphorus-containing flame retardant on the thermal properties and ease of ignition of poly(lactic acid), Polymer Degradation and Stability 96(9): 1557-1561. http://dx.doi.org/10.1016/j.polymdegradstab.2011.05.018

Wilkie, C. A.; Morgan, A. B. 2009. Fire retardancy of polymeric materials. Taylor \& Francis. 823 p.

Zowada, J. 2010. Badanie rozkładu temperatur w pomieszczeniu zamkniętym podczas spalania modyfikowanych $i$ nie modyfikowanych materiałów poliestrowych [Investigation of the changes in temperature field during combustion of modified and unmodified polyester materials]. MsC Thesis, SGSP.

Jerzy GAŁAJ. PhD, the head of Hydromechanics Division at the Department of Fire Safety Engineering, the Main School of Fire Service, Warsaw. Publications: the author of over 50 scientific publications. Research interests: fire modelling, modelling of extinguishing systems, fire safety engineering, full-scale fire tests, flow characteristics of fire fighting systems.

Marzena PÓLKA. Associate Professor, Dr Habil, the Dean of the Department of Fire Safety Engineering, the Main School of Fire Service, Warsaw. Publications: the author of over 50 scientific publications. Research interests: combustion of polymer materials, cone calorimeter methods, thermal properties of materials, dust explosion.

Ritoldas ŠUKYS. Associate Professor, Dr, the Head of the Department of Labour Safety and Fire Protection, Vilnius Gediminas Technical University (VGTU). Publications: the author of over 36 scientific publications. Research interests: human safety, safety engineering. 